the depression may have been coincidental. Evidence against this, however, is the relation between the premorbid postviral fatigue and the later onset of depression, the temporal relation between the encephalopathy and depression, and the rarity of delusional depression at this age. Although delirium is the commonest psychiatric presentation of encephalitis, delusional depression also occurs. ${ }^{5}$

A latent period between the acute infection and depression has been noted with milder depressive illnesses ${ }^{1}$ and neurological disorders. ${ }^{4}$ Delusional depression may be a late complication of infectious mononucleosis that may signal, and perhaps be mediated by, an encephalopathy.

We are grateful to Dr K Bergman and Dr M Trimble for permission to report these cases.

1 Hendler N, Leahy W. Psychiatric and neurological sequelae of infectious mononucleosis. Am $\mathcal{J}$ Psychiatry 1978;135:842-4.

2 Cadie M, Nye FJ, Storey P. Anxiety and depression after infectious mononucleosis. Br f Psychiatry 1976;128:559-61.

3 Anonymous. EBV and persistent malaise [Editorial]. Lancet 1985; $1: 1017-8$.

4 Grose C, Henle W, Henle G, Feorino PM. Primary Epstein-Barr virus infections in acute neurological diseases. N Engl f Med 1975;292:392-5.

Sobin A, Ozer MN. Mental disorders in acute encephalitis. Journal of the Mount Sinai Hospital 1966;33:73-82.

(Accepted 9 April 1987)

Department of Psychological Medicine, St Bartholomew's Hospital, London EC1A 7BE

P D WHITE, MRCP, MRCPSYCH, Mental Health Foundation training fellow

Genetics Section, Institute of Psychiatry, London SE5 8AF

$S$ W LEWIS, MPHIL, MRCPSYCH, lecturer

Correspondence to: Dr White.

\section{Unorthodox internal fixation of bone lesions in myelomatosis}

In myelomatosis there is no relation between the presence of bony lytic lesions at presentation and the length of survival. ${ }^{1}$ These lesions may be without symptoms or they may be painful, but where extensive lesions occur there is a high risk of pathological fracture or vertebral collapse. When fractures occur local radiotherapy and internal fixation are standard treatments.

\section{Case report}

An otherwise fit woman of 67 presented in July 1984 with a three week history of pain in the right shoulder, which she ascribed to vigorous housework. Tests showed a normal blood count and erythrocyte sedimentation rate $7 \mathrm{~mm}$ in first hour). The results of biochemical investigations, including urea and electrolytes, liver function tests, plasma protein electrophoresis, serum creatinine, creatinine clearance, and serum calcium were within normal limits. Immunoglobulins were normal apart from a reduced IgA concentration of $10 \mathrm{~g} / \mathrm{l}$ (normal $12-50 \mathrm{~g} / \mathrm{l}$ ). Urine electrophoresis showed an $M$ band, which was proved to be Bence Jones protein by immunofixation. Bone marrow smears contained $10 \%$ plasma cells with many morphological abnormalities. A radiograph of the right arm showed a large lytic lesion almost replacing the upper third of the humerus. A few small lesions were noticed also in the pelvis, right scapula, and skull.

Myelomatosis was diagnosed. She was started on a standard dose of melphalan, prescribed analgesics, and encouraged to drink a lot of fluid. After four months of outpatient treatment urinary excretion of protein was reduced but she fel increasing pain in the right shoulder and weakness in the arm. Another radiograph (figure (left)) showed an extension of the lytic lesion with thin areas of cortex in the shaft of the humerus. It was considered that local radiotherapy would probably precipitate a pathological fracture, and it was decided to strengthen the humerus by injecting orthopaedic cement.

The head and upper shaft of the humerus were exposed through an anterior approach. The bone was reduced to a thick shell and the tumour had extended anteriorly into the deltoid muscle. The bone was too thin to risk curettage of the tumour; it was removed by suction from a straight metal sucker under radiological control. Radio-opaque methyl methacrylate was injected under radiological control by means of a "cement gun" that had disposable plastic containers. Two containers of cement were needed to fill the humerus but there was no systemic reaction to the setting of this unusually large amount of cement. A radiograph taken after the operation showed a solid column of cement filling (figure (right)). She was discharged home three days later, and the wound healed uneventfully. The arm remained functional for 18 months apart from some limitation of movement at the shoulder joint, and she continued running her home. During this time radiographs showed no changes and radiotherapy was not necessary. In August 1986 she was admitted with a collapsed T8 vertebra and incipient paraplegia; this progressive paraplegia confined her to a wheelchair. She died of complications due to chemotherapy.

\section{Comment}

Methyl methacrylate is extensively used in hip and other joint replacements. ${ }^{23}$ Toxic effects include allergic reactions and damage to the normal function of neutrophils. ${ }^{4}$ There are also reports of cardiorespiratory side effects due to monomer diffusing out of the polymerising cement mass. In our patient the heat generated by the setting cement and its toxic effect on cells may have helped suppress plasma cells and osteoclast activity. ${ }^{5}$

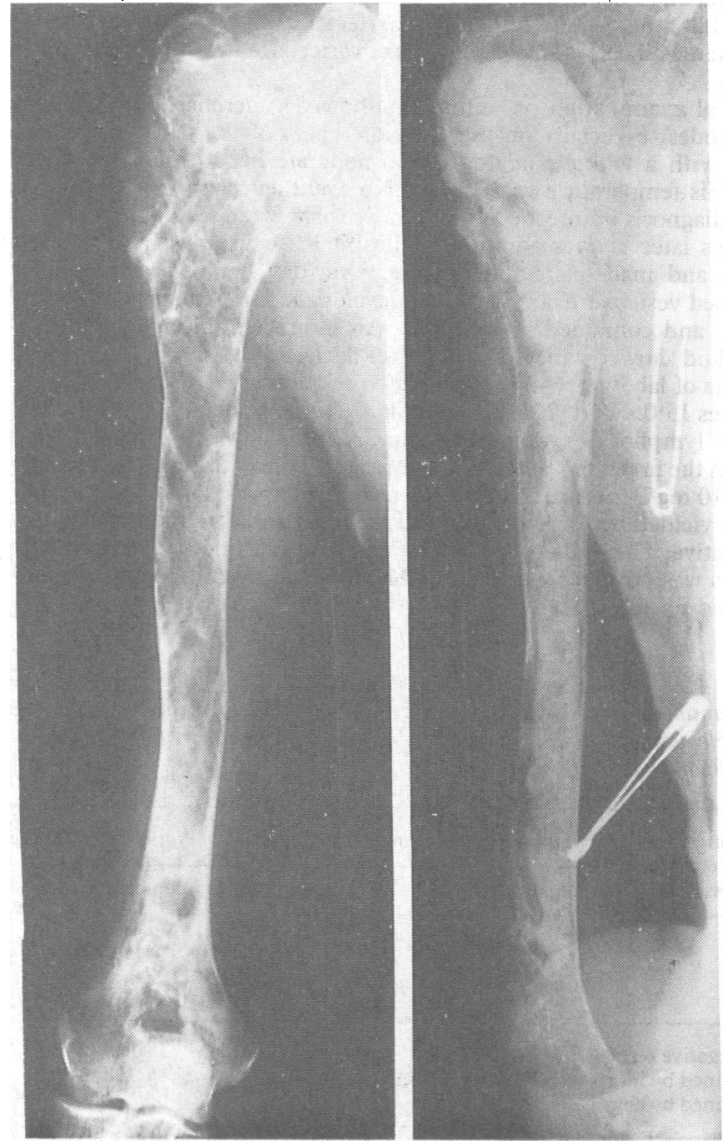

Radiographs of humerus (left) before and (right) after surgery

Our satisfactory results may have been because the general condition of the patient was excellent and the only large bony lesions were in the right humerus. We are not aware that this method of internal fixation has been used before in myelomatosis; it may be applicable to lytic lesions in other sites.

1 Buckman R, Cuzick J, Galton DAG. Long term survival in myelomatosis, Br f Haematol 1982:52:589-99.

2 Scales JT. Bone and joint replacement for the preservation of limbs. $\mathrm{Br} \mathrm{J} \mathrm{Hosp} \mathrm{Med}$ 1983;30:220-32.

3 Nixon J. Non-cemented hip prosthesis. BrMed J 1985;290:1680-2.

4 Petty $W$. The effect of methyl methacrylate on bacterial phagocytosis and killing of human polymorphonuclear leucocytes. Bone foint Surg [Am] 1978;60:2-7.

5 Durie BGM, Schmon SE, Mundy GR. Relation of osteoclast activating factor production to exten of bone disease in multiple myeloma. Br f Haematol 1981;47:21-30.

(Accepted 15 April 1987)

Department of Haematology and Orthopaedic Surgery, Hillingdon Hospital, Uxbridge, Middlesex UB8 3NN

ALENA KUBIE, MD, CHB, clinical assistant in haematology

P I BUSFIELD, FRCS, consultant orthopaedic surgeon

R P BRITT, MB, FRCPATH, consultant haematologist

Correspondence to: Dr Kubie. 